\title{
THE ENVIRONMENTAL CONDITIONS OF A LOCATION MAY INFLUENCE THE TREATMENT OF INDUSTRIAL SOLID WASTE
}

\author{
Morán-Palacios, H. * - Mesa-FernándeZ, J. M. - ÁlvareZ-CABAl, J. V. - MartíneZ- \\ HUERTA, G. M. \\ Project Engineering Department, University of Oviedo, Oviedo 33004, Spain \\ *Corresponding author \\ e-mail: henar.moran@api.uniovi.es; phone: +34-985-104-272; fax: +34-985-104-256
}

(Received 29 $9^{\text {th }}$ May 2019; accepted $25^{\text {th }}$ Nov 2019)

\begin{abstract}
The management of industrial solid waste demands the establishment of suitable management systems. Such systems must take into consideration multiple factors that allow selecting the most adequate treatment techniques among the ones available. The selection of these techniques is a complex process that not only depends on factors inherent to the treatment or the waste itself, but also on other factors. For this reason, this study analyses the influence of location on the management of an industrial solid waste such as LD sludge. Firstly, we used a methodology developed in a previous part of this study, that can identify six treatment solutions, then, a set of environmental, regulatory and socioeconomic indicators are chosen. Going a step further in this investigation, proves through the application of the methodology in five different locations, that environmental characteristics influence the final treatment solution for the same waste. According to this, two sets of groups can be identified for the best treatment solution: one in which the highest score is 1 A Ceramization and another in which the final result is $1 \mathrm{~B}$ Vitrification.
\end{abstract}

Keywords: sludge, analytical hierarchy process, management methodology, system of indicators, industrial facilities

\section{Introduction}

Over the course of history, and as the population has grown, the needs and level of comfort for individuals have increased exponentially, resulting in an excessive generation of waste parallel to the generation of goods. This lack of social conscience that until recently was undeniable, dumping this waste in an uncontrolled manner and causing serious economic, social and environmental problems, has been giving way to the emergence of a new social conscience.

The problem of environmental pollution has its origin in the fast urbanization and industrialization produced in the last few decades. Although the amount of waste produced in cities is worrying, the generation of waste at the industrial level is even more so. In spite of being more varied and numerous, they are more dangerous and, as a consequence, more difficult to control, causing serious problems in the operations of their use and subsequent disposal. This, in combination with greater social awareness, makes the need to develop new management methods and procedures becoming more and more evident. However, just as important as their development is the way they are applied and adapted to the constantly changing technological and social environment. One-way to go a step further and make the most of these management systems, is to incorporate specific tools that allow the influence of certain external agents to be measured.

Therefore, the industrial solid waste management (ISWM) is a complex issue that industrial companies around the world must tackle on a daily basis. All of them must try 
to use the best techniques available to treat the waste material and establish the most suitable management and treatment systems.

In many cases, the selection of the most suitable treatment or set of treatments is a complex issue, due to the need to bear in mind a considerable amount of factors (technical, economic, social...). Obviously, the special characteristics of the industrial waste are often crucial, though the environmental conditions of the area where the waste is generated are also decisive.

In the managing of industrial solid waste (ISW) or any type or waste, not only should be taken into account, to study which treatment is the best according to the characteristics of the waste, if not that the process is much more complex. In addition, the performance produced should be analysed according to the environmental characteristics of the site or location where it is to be managed. Based on the measurement of this performance, it could be decided which environment is best to treat the waste.

Based on this hypothesis, it might appear that the research currently being carried out on this particular subject could be countless, but this is not the case. Since many of the existing works only study the optimal location of the industrial facilities to reduce its impact from the beginning using decision support systems (Arán et al., 2008) or multicriteria decision making techniques (Çebi and Otay, 2015) including Analytic Hierarchy Processes (Kauko, 2006; Dey and Ramcharan, 2008; Srdjevic et al., 2007; Akınc1 et al., 2013). Other researches use bi-level programming models (Wu and Yang, 2018) or analyse (Chen et al., 2014) or compare (Glatte, 2015) different models.

Some authors study the optimal location of the treatment plants using multi-criteria approaches, taking into account technical, economic and environmental aspects (Önüt and Soner, 2008; Wibowo and Grandhi, 2017; Wójcik et al., 2014; Kyriakis et al., 2017; Samah et al., 2017; Ulubeyli et al., 2017). For this purpose, different techniques and methodologies are used, including Analytic Hierarchy Processes (Önüt and Soner, 2008; Milutinović et al., 2014; Samah et al., 2017), programming models (Vaillancourt and Waaub, 2002; Haastrup et al., 1998; Paul et al., 2018), or fuzzy systems (Carniel and Schneider, 2017; Abdulhasan et al., 2019). Other select the most appropriate treatments for waste at a given location (Achillas et al., 2010; Xu et al., 2014; Nouri et al., 2018) or a comparison between two locations (Milutinović et al., 2016; Inglezakis et al., 2018).

Thus, the work here presented pursues two goals:

- Check that the environmental conditions of a location can modify the most suitable treatment for a specific industrial waste.

- Verify that the previously developed methodology by the authors (Fernández et al., 2014) is capable of providing the best solution in several geographical locations with different physical, environmental and social conditions where the waste material is generated.

\section{Materials and methods}

\section{Methodology for the ISWM}

As described above, the methodology for the selection of the most suitable solution for the waste material that has been used, is the one defended by Fernández et al. (2014) 
This methodology has a series of characteristics that makes it the most suitable for the study of the treatment of industrial solid waste:

- First, its adaptability to any type of waste, either solid or semisolid.

- It can be applied to any type of environment by adjusting the location conditions of the installation where the management process is taken place (climate, soil, closeness to populated areas or green areas, etc.).

- It is a flexible methodology that can consider different criteria or environmental indicators.

- It is user-friendly, since the decision process guides and helps users through the different options.

- It is easy to update, by including new treatment methods, changes derived from evolution in technology or social and economic conditions.

All these characteristics allow the methodology to continue evolution and thus be able to comply with the future lines contemplated in the first part of the study developed in Spain (Fernández et al., 2014). For its application, the methodology is structured in four stages, defined in Figure 1.

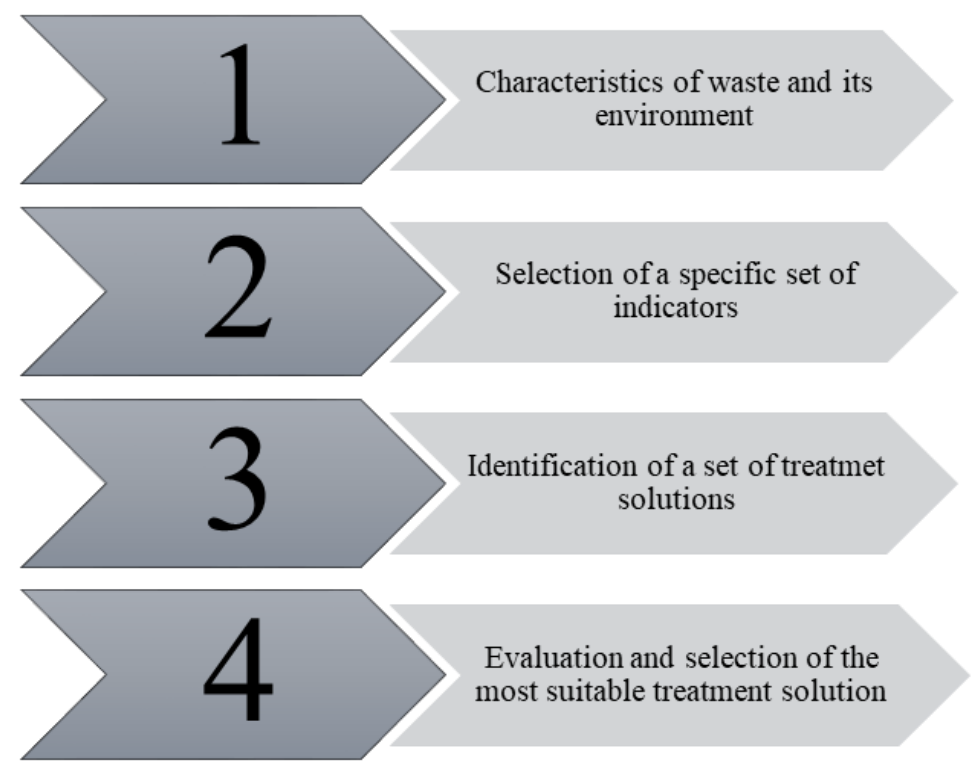

Figure 1. Methodology development diagram

The first thing to learn is the characteristics of the waste to be treated and the environment where the treatment will be developed. All this information is then collected in files or sheets, one with the characteristics of the waste material and the other with those of the environment, the first classifies the waste material according to information related to its identification, and the second collects information on the location where the treatment system will be set and its conditions.

The second stage involves the selection of a specific set of indicators for each case of application, the result of particularizing a system of general indicators.

For this purpose, the general Environmental Indicator System (EIS) for any area of the company, will be specific to waste management by configuring a System of Environmental Indicators for Solid Waste Management (SEISWAM) that will be the 
means of subsequent evaluation of the possible treatment solutions applicable to this waste. The characteristics of the indicators are described in the "Indicator sheet".

In the third stage, the treatment solutions are identified thanks to an "alternative selection chart" (Fernández et al., 2014), which presents the necessary process for the treatment of a solid waste from its generation to its disposal, elimination or reuse, and functions as a decision aid system. This identification is carried out taking into account the characteristics of the waste "Waste sheet" and the set of available techniques, "Process sheet", which collects the main data of interest of each technique and waste to which is applicable. Each of these solutions can consists of more than one treatment process.

The last stage of the methodology presents the results of the study and allows us to select the most suitable solution among all the possible solutions previously identified in the previous stage. For this purpose, the selected set of indicators is available, which evaluates each of the available solutions. This evaluation is performed through the application of the Analytical Hierarchy Process (AHP), developed by Tomas Saaty in 1980 (Saaty, 1980).

\section{Case study}

Next, the application of this methodology to a particular case is described, where the goal is to search the optimal treatment solution for the same industrial waste in different locations worldwide.

\section{Waste product studied}

LD converter sludge is the waste material resulting from the wet processing of gas in the steel-making process in the Basic Oxigen Furnace (BOF) converter or LD converter, named after the Austrian towns Linz and Donawitz where this system was first developed. This waste material involves a serious concern due to the vast amount generated, around $27 \mathrm{~kg}$ of LD sludge per ton of hot metal. Its physical and chemical components allow different alternatives or possibilities of treatment. On the other hand, it has a percentage of recoverable material, its metal part, which makes it a reusable product both for the steelmaking and other types of industries (Table 1).

\section{Selection of locations}

In order to develop this study, 5 populations close to steel mills have been selected, where the LD slag is obtained and which have different physical, environmental and social environment conditions.

Among the possible locations, areas with different climate conditions have been selected, according to the climate classification developed by Köppen. This procedure is based on empirical observations (Köppen, 1900) to establish a climate classification system that uses monthly temperatures and rainfalls to define the limits of the different types of climate worldwide. This classification was revised and updated afterwards (Köppen and Geiger, 1930, 1936; Stern et al., 2000; Peel et al., 2007) and it is widely used worldwide by meteorologists and geologists (Chen and Chen, 2013; Feng et al., 2014), apart from being the base of multiple scientific studies (Pražnikar, 2017; Almorox and Quej, 2015; Yoo and Rohli, 2016).

According to these premises, the populations of Avilés (Spain), Lázaro Cárdenas (Mexico), Tubarao (Brazil), Newcastle (South Africa) and Beijing (China) were 
selected for the study. The climatological conditions of these locations are displayed in Table 2. In the case of Spain, the data have been obtained from the State Meteorological Agency (AEMET, 2017) and the data of the rest of the locations have been collected from the WMO repository, World Meteorological Organization (WMO, 2017), from the official website of the NOAA, National Oceanic and Atmospheric Administration, which belongs to the USA Government.

Table 1. Waste characterization

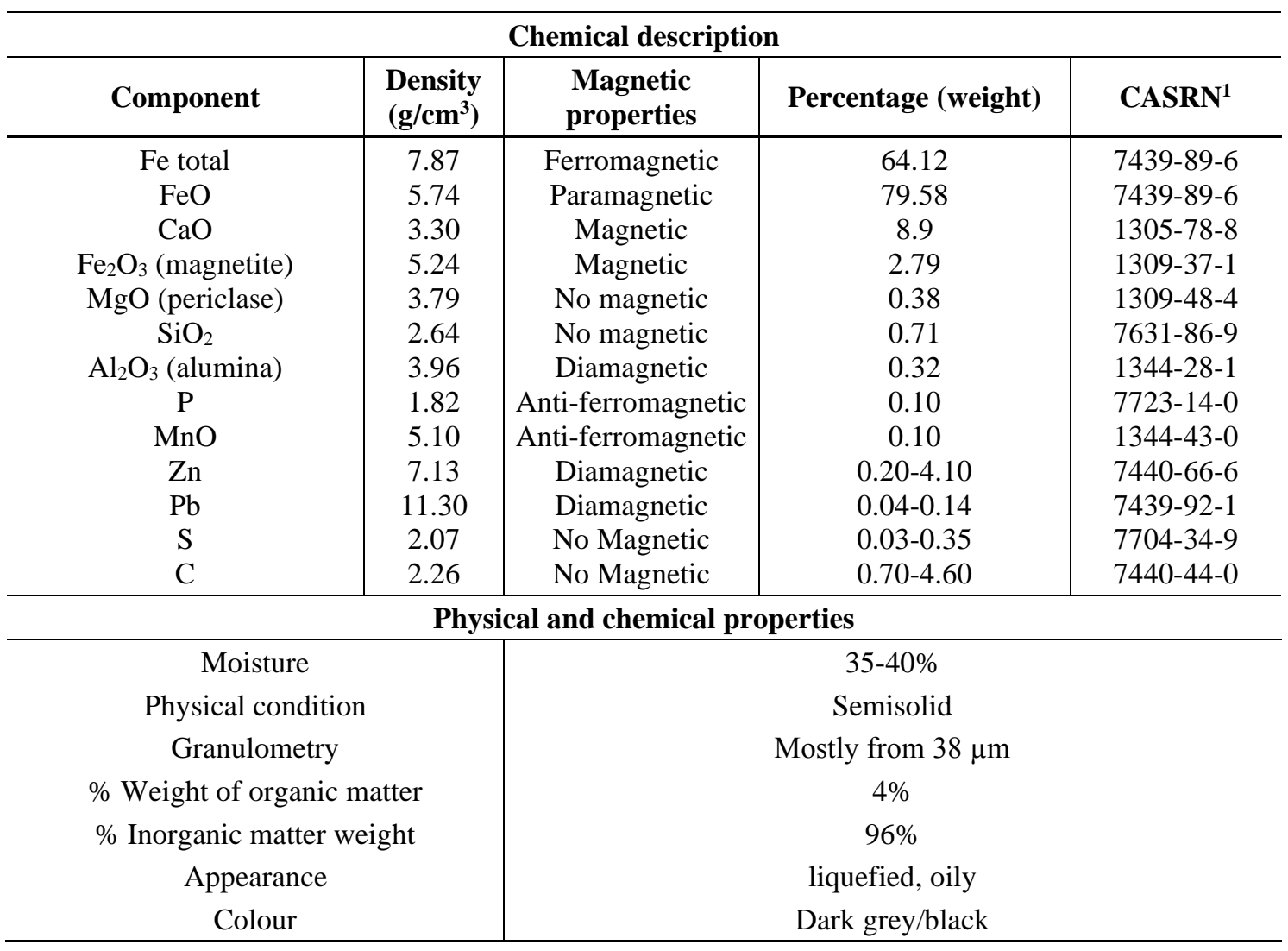

${ }^{1}$ Chemical Abstract Service Register Number (American Chemical Society)

The town of Avilés is located in the North East coast of Spain, with mild temperatures in all seasons, with and average temperature of $13.5^{\circ} \mathrm{C}$, high relative humidity $(78 \%)$ and frequent rain. On the contrary, Newcastle (South Africa) has a drier climate, with lower relative humidity $(59 \%)$ but higher average temperatures $\left(21.9^{\circ} \mathrm{C}\right)$ and less rainfall. On the other hand, Lázaro Cárdenas, a town located near the Pacific Coast of Mexico, has a tropical rainforest climate, where winters are cold but the average annual rainfall is still high all year around. The average rainfall level is $1278 \mathrm{~mm}$ and temperatures are high, with an average temperature of $27^{\circ} \mathrm{C}$ and a high relative humidity. The humidity of the Brazilian city of Tubarao $(61 \%)$ is lower than the case of Mexico, while the temperatures are also high $\left(26.4^{\circ} \mathrm{C}\right)$, with a lower rainfall level than in the previous case $(1,003 \mathrm{~mm})$, although relatively similar to the town of Avilés. 
In Beijing, the weather conditions are quite similar to those of the city of Newcastle in South Africa, although it is colder, $\left(11.8^{\circ} \mathrm{C}\right)$ and drier $(47 \%)$, and the level of rainfall is a bit higher $(577 \mathrm{~mm})$ than that of the Chinese capital.

Table 2. Climate characteristics according to location

\begin{tabular}{|c|c|c|c|c|c|}
\hline & BOF & BOF & BOF & BOF & BOF \\
\hline Steel mill & Avilés (Spain) & $\begin{array}{c}\text { Lázaro } \\
\text { Cárdenas } \\
\text { (Mexico) }\end{array}$ & $\begin{array}{l}\text { Tubarao } \\
\text { (Brazil) }\end{array}$ & $\begin{array}{c}\text { Newcastle } \\
\text { (South Africa) }\end{array}$ & Beijing (China) \\
\hline Measure location & Avilés & Acapulco & Sao Goncalo & Johannesburg & Beijing \\
\hline Site & Industrial & Rural-town & Rural & Industrial & Industrial \\
\hline $\begin{array}{c}\text { WMO number } \\
\text { station }\end{array}$ & NA & 76805 & 82689 & 68368 & 54511 \\
\hline Period (years) & $1981-2010$ & $1961-1990$ & 1961-1990 & 1961-1990 & $1961-1990$ \\
\hline $\begin{array}{l}\text { Type of climate } \\
\text { according to } \\
\text { Köppen }\end{array}$ & $\begin{array}{c}(\mathrm{Cfb}) \\
\text { warm/very } \\
\text { wet/warm } \\
\text { summer }\end{array}$ & $\begin{array}{l}\text { (Aw) tropical } \\
\text { rainforest } \\
\text { climate/dry } \\
\text { winter }\end{array}$ & $\begin{array}{c}\text { (Cfa) } \\
\text { warm/very } \\
\text { wet/hot summer }\end{array}$ & $\begin{array}{c}(\mathrm{Cwb}) \\
\text { warm/dry } \\
\text { winter/warm } \\
\text { summer }\end{array}$ & $\begin{array}{c}\text { (Cwa) } \\
\text { warm/dry } \\
\text { winter/hot } \\
\text { summer }\end{array}$ \\
\hline Distance $(\mathrm{km})$ & 0 & 300 & 510 & 289 & 0 \\
\hline $\begin{array}{l}\text { Annual average } \\
\text { temperature }\left({ }^{\circ} \mathrm{C}\right)\end{array}$ & 13.50 & 27.50 & 26.4 & 21.90 & 11.80 \\
\hline $\begin{array}{l}\text { Annual average } \\
\text { humidity }(\%)\end{array}$ & 78 & 75.80 & 61 & 59.20 & 47 \\
\hline $\begin{array}{l}\text { Anual rainfall total } \\
(\mathrm{mm})\end{array}$ & 1,062 & 1,278 & $1,003.30$ & 543 & 577 \\
\hline $\begin{array}{c}\text { Annual average } \\
\text { wind speed }(\mathrm{m} / \mathrm{s})\end{array}$ & 3.50 & 2.20 & 2.82 & 2.78 & 2.50 \\
\hline Data source & AEMET & WMO & WMO & WMO & WMO \\
\hline
\end{tabular}

When selecting these populations, apart from the different climate characteristics, the type of location has also been taken into account, that is, if it is an industrial or rural area and if it is near or not to population centres or natural reserves. In this sense, Avilés, Newcastle and Beijing are considered as populations located in industrial areas, against Tubarao and Lázaro Cárdenas, which are closer to rural areas with small population centres and close to areas considered as natural heritage.

\section{Selection of a specific set of indicators}

The indicators system has been established as one of the most useful tools for monitoring the process information flows, which provide us with techniques to evaluate their efficiency.

The so-called SEISWAM was developed at the same time as the methodology used in this paper (Fernández et al., 2014) and it is based on the following two former systems:

- The first one is based on a system of indicators in which the principles of ISO 14031 standard are specified (ISO International Organization for Standardization), the European eco-management and audit scheme contained in the EMAS Regulation (Comision Europea, 2003; DOUE, 2009), extended with 
the present classification in the report issued by the Public Society of Environmental Management of Basque Government IHOBE (IHOBE, 1999).

- The second one is the GRI system (Global Reporting Initiative), which is the main international standard for the drafting of Sustainability and Corporate Social Responsibility Reports (CSR) (GRI, 2005).

The indicators system is specialized in the management of industrial solid waste by using a selection chart to define the methodology of waste management. This gives a more complex system called SEISWAM, which is comprised of hundreds of indicators.

Among these indicators, the most representative ones in terms of measuring the impacts of inputs and outputs processes were selected resulting eleven (Table 3). These indicators collect globally the different environmental impacts (environmental indicators), socioeconomic impacts (financial behaviour indicators) and those affecting the management process according to the set of treatments that waste endures (environment indicators).

Table 3. Indicators considered

\begin{tabular}{c|c}
\hline Number & Indicator name \\
\hline 1 & Specific energy consumption \\
2 & Specific water consumption \\
3 & Specific consumption of chemical agents \\
4 & Volume of liquid effluents \\
5 & Volume of gas emissions \\
6 & Total share of profitable solid \\
7 & Operational costs of environmental protection \\
8 & Average rainfall of the area where the installation is located \\
9 & Wind speed in relation to the average in the area where the installation is located \\
10 & Proportion of natural heritage affected \\
11 & Proximity to local populations \\
\hline
\end{tabular}

Of these eleven indicators, the first seven are dependent on the characteristics of the waste material and measure the environmental, social, economic impacts of the waste management process. Essentially, it has been decided to select those that directly and easily quantify the inputs and outputs in the flowchart, to compare the results obtained with those of the first part of the study carried out by Fernández et al. (2014). For instance, the indicator 'Specific water consumption' has been selected over other possible ones like 'Rate of type of water", because the latter does not evaluate all the water in the whole process, but only of those processes that work with a certain type of water. The same happens with indicators concerning chemical agents, effluents and gas emissions.

The selection of the indicator 'Operating costs of environmental protection' incorporates the economic impact from the viewpoint of environmental protection related to the operations performed in the waste management facility. This is not the case in other possible suitable indicators such as 'Environmental aid granted by the Government' in which, besides taking into account mainly economic factors, there is no reference whatsoever to the management process. 
Regarding the quantification of the system outputs, in the case of the indicator 'Total share of profitable solid', this more global indicator has been chosen rather than 'Total amount of profitable solid with respect to energy consumption', in which the usable solids are quantified, but only taking into account the input of energy to the process.

Regarding the indicators corresponding to the environmental conditions that affect the treatment processes, it has been selected the ones referring to the climate characteristics of the area most liable to affect the waste treatment system, such as rainfall and speed. Regarding the living conditions, the most representative indicators of this level have been chosen, such as the 'natural heritage affected' and the 'Proximity to local populations' without going into details about the classification or type of soil (rural or urban).

\section{Set of treatment solutions}

By the 'alternative selection chart' (Fernández et al., 2014) the different treatment solutions are identified, obtaining six possible treatment alternatives:

- Alternative 1 A. Ceramization

- Alternative 1 B. Vitrification

- Alternative 2.1 A. External manager of hazardous solids

- Alternative 2.2 A. Phytoremediation

- Alternative 2.2 B. Bioremediation

- Alternative 2.2 C. On site vitrification

Each of these alternatives is comprised of a set of treatments that start when the waste enters the facility and ends when the final product is obtained. To summarize, they are identified only with the name of the last valorization treatment applied to the waste. The treatments that constitute each alternative are described below.

In the alternative selection chart, the waste material goes through a series of initial considerations such as its categorization as a non-radioactive, hazardous and valuable slag, according to its initial classification. Afterwards, the sludge is dried to be submitted to a magnetic separation process. As a result, the solid magnetic fraction is usable while the non-magnetic part goes back into the decision process. This nonmagnetic solid could be recovered (alternative 1) or not (alternative 2). If the recovery of such fraction is chosen, it would be possible to apply the treatments of ceramization (Alternative $1 \mathrm{~A}$. Ceramization) or vitrification (Alternative $1 \mathrm{~B}$. Vitrification). In the case of not choosing to recover the waste material (alternative 2), it must be determined if it is legally disposable or not. In this particular case, it would not be disposable, since, according to the legislation and the initial characterization, this waste material contains a series of toxic components that surpass the legal thresholds. Therefore, at this point, there are two options. The first one would be not treating the waste internally but carrying it instead to an External manager of hazardous solids (Alternative 2.1 A). The second one would be treating the waste internally, with these different treatment possibilities: Phytorremediation (Alternative 2.2 A. Phytoremediation), Bioremediation (Alternative 2.2 B. Bioremediation) or onsite vitrification (Alternative $2.2 \mathrm{C}$. On site vitrification). 


\section{Results}

The five proposed locations are assessed using the eleven selected indicators that constitute the decision criteria of the AHP method (Fernández et al., 2014), which corresponds to the last stage of the methodology, Evaluation of alternatives, giving the results of the study. This way, the influence of weather conditions is opposed to the proximity to population areas, industrial zones, rural areas, nature reserves, etc. in the treatment processes. In this stage, the environmental impacts are taken into account when assessing the indicators. Therefore, each management solution will have a different score.

In the calculation of the judgment matrix by paired comparison of the treatment alternatives for each of the criteria or indicators related to the environment, the weights of each of these criteria vary depending on each location. For instance:

- In damp and rainy locations, landfill treatments produce more leachates than in drier climates. As a consequence, in Avilés or Lázaro Cárdenas, a higher quantity of liquid effluents and alternatives such as 2.2 A Phytoremediation and $2.2 \mathrm{~B}$ Bioremediation would be generated and, therefore, they receive a worse assessment than others such as $1 \mathrm{~A}$ Ceramization. On the contrary, Newcastle and Beijing have a lower amount of effluents and the alternatives 2.2 Phytorremediation and 2.2 B Bioremediation obtain a better assessment.

- In locations with high wind speed, gas pollution moves to other nearby areas such as population centres or natural parks. In these cases, the criteria or indicators 'Affected natural heritage' or 'Operational costs of environmental protection', become negative factors or criteria when assessing certain treatments. This would be the case of towns such as Avilés or Tubarao, where the scores of valorization processes such as ceramization or vitrification are lower than those corresponding to landfill or shipping to an external manager of hazardous solids.

Taking into account this calculation and the weights of indicators according to the area where the treatment facility is located, the following scores are obtained in Table 4.

Table 4. Hierarchical analysis method solutions in different locations

\begin{tabular}{c|c|c|c|c|c}
\hline \multirow{2}{*}{ Alternatives } & \multicolumn{5}{|c}{ Alternative priority vector } \\
\cline { 2 - 6 } & $\begin{array}{c}\text { Avilés } \\
\text { Industrial }\end{array}$ & $\begin{array}{c}\text { Lázaro Cárdenas } \\
\text { Rural }\end{array}$ & $\begin{array}{c}\text { Tubarao } \\
\text { Rural }\end{array}$ & $\begin{array}{c}\text { Newcastle } \\
\text { Industrial }\end{array}$ & $\begin{array}{c}\text { Beijing } \\
\text { Industrial }\end{array}$ \\
\hline 1 A Ceramization & $\mathbf{0 . 2 6 3 5}$ & $\mathbf{0 . 2 7 0 5}$ & $\mathbf{0 . 2 6 0 2}$ & 0.1857 & 0.1857 \\
1 B Vitrification & 0.2429 & 0.2516 & 0.2459 & $\mathbf{0 . 1 9 2 3}$ & $\mathbf{0 . 1 9 3 7}$ \\
2.1 External manager of hazardous solids & 0.2386 & 0.2381 & 0.2371 & 0.1801 & 0.1788 \\
2.2 A Phytoremediation & 0.0794 & 0.0882 & 0.0803 & 0.1776 & 0.1853 \\
2.2 B Bioremediation & 0.0692 & 0.0702 & 0.0703 & 0.1378 & 0.1393 \\
2.2 C On site vitrification & 0.1063 & 0.0814 & 0.1062 & 0.1265 & 0.1173 \\
\hline
\end{tabular}

It can be noticed that the best-valued treatment alternative in each location, that is, the one with the highest value or score, vary in the different sites. The alternative 1A. Ceramization is the preferred option in the first three locations (Avilés, Lázaro Cárdenas and Tubarao) while in the other two (Newcastle and Beijing) the highest score is for alternative 1B Vitrification. 
In all cases, a better assessment is given to the alternatives that end with the waste valorization (ceramization and vitrification) compared to those of final treatment (landfill, - phytoremediation and bioremediation - and external manager).

\section{Discussion}

According to the solution proposed by the methodology as the most suitable one, two sets of groups can be identified: one in which the highest score is 1 A Ceramization and another in which the final result is $1 \mathrm{~B}$ Vitrification.

In order to describe in a better way what is observed in Table 4, the distribution of two localities is shown in Figure 2, Lázaro Cárdenas belonging to the first site and Beijing belonging to the second, in the first case, the scores appear more concentrated in the treatment processes and external manager, while in the second the scores are similar.

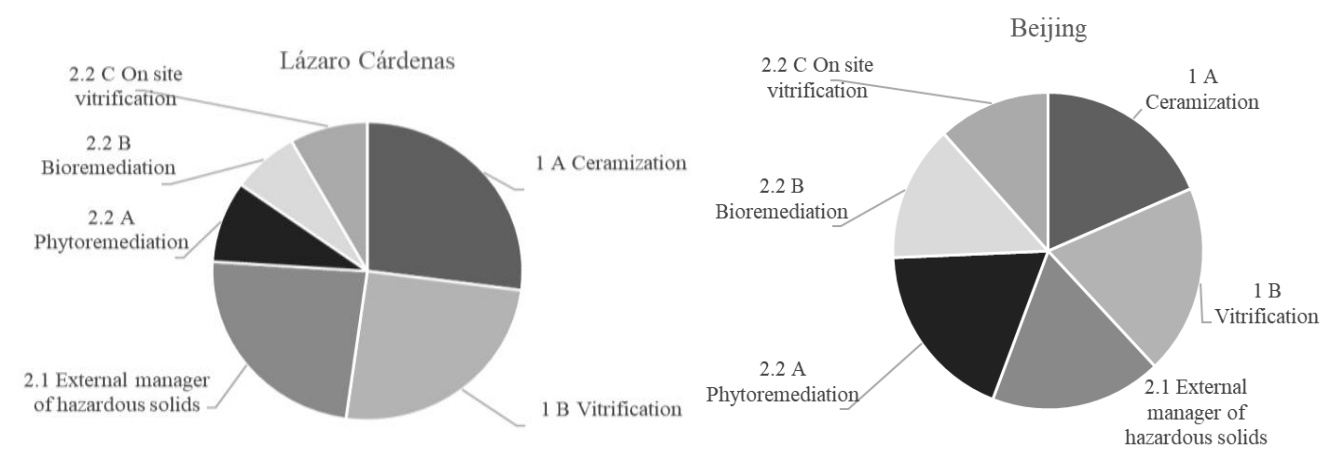

Figure 2. Priorities of treatment alternatives according to location

The scores given by the experts to the different treatment alternatives in the comparative analysis, depending on the selected criteria or indicators, vary due to the following causes:

1. Leachates can appear in damp and rainy climates so, as a consequence, the landfill treatment alternatives (phytoremediation and bioremediation) have poorer scores. This is what occurs in the first three locations (Avilés, Lázaro y Tubarao), for having more rainfall than the other two (Newcastle and Beijing).

2. On the other hand, the landfill treatment alternatives obtain higher scores for the good results obtained by these techniques in climates with less rainfall, as in the case of Newcastle. According to different studies (Sharma and Pandey, 2014; Liphadzi et al., 2005) the plants and microorganisms used in these areas (Yadav and Hassanizadeh, 2011; Hejazi et al., 2003) develop their activity effectively by clearing the soil of heavy metals due to favorable weather conditions.

3. Gas emissions occurring near rural areas where the natural habitat is more diverse, such as Lázaro Cárdenas and Tubarao, generate more environmental impact than in industrial areas, which favours the scoring of alternatives that include landfilling, such as 2.2 A Phytoremediation, 2.2 B Bioremediation, diminishing the scoring of the alternatives that do not include it, such as $1 \mathrm{~B}$ Vitrification and 2.1 A External manager. These impacts also occur in Aviles, 
but since it has an industrial environment, the natural and rural heritage is less affected, so landfill scores do not rise as much as in rural locations.

4. Wind speed is similar in all studied locations, although the highest wind speed corresponds to Avilés. In this area, emissions in the form of leaks that can break into the atmosphere are more likely to be dragged to further area, thus extending the range of pollution. This makes the valorization processes more expensive than those of landfilling or manager dispatching. On the contrary, the opposite case occurs in the rest of the locations where the wind speeds are softer.

In the first analysis, the operability of the methodology was proved (Fernández et al., 2014), a locality with specific environmental conditions was chosen and the scores of the treatment alternatives were calculated, being the highest alternative $1 \mathrm{~A}$ ceramization.

In this research, in which the type of waste and the evaluation criteria are the same, besides demonstrating the characteristics of the methodology described in the materials and methods section; adaptability, applicability, flexibility, user-friendly, easy to update; the treatment solutions obtained in each of the five locations have been compared, it can be observed that the changes in the environmental conditions of the site established at the beginning of the analysis differ significantly, therefore the evaluation of the indicators changes and, consequently, the results vary.

\section{Conclusions}

This study has implemented the methodology by Fernández et al. (2014) in order to select the most suitable treatment alternative to the same waste in five different locations. The results obtained show that the best solution may vary when environmental conditions are significantly changed.

In the case studied, the treatment of LD sludge, when analyzing the influence of the climatic and environmental conditions of the location in the different treatment processes, the following results were obtained:

A high-level rainfall constrains the suitability of the landfill treatments, since in this context there is a higher-level generation of leachates.

- The gas emissions produced at the output of some treatments (vitrification or ceramization), combined with the wind conditions may have a negative impact in rural locations or other places, as for instance natural reserves or protected areas. This makes these treatments less suitable. On the contrary, if these conditions are in industrial areas or its proximity, it has a less negative impact.

- In the case of the developed methodological process, a series of inherent characteristics of the methodology are reviewed and checked:

- Its applicability and flexibility, allow the use of the most suitable criteria or environmental indicators in each case, more or less according to the number of criteria of study required for each case.

- Its simple upgrading. This makes it easier to add new waste treatment techniques to the valorization decisions or treatment requirements included in the alternative selection chart. 
Within the future lines of research in this study, the analysis developed can be perfectly extended to other similar facilities located in other cities under different climatic and environmental conditions, being able to obtain a different solution in a changing environment.

The same methodology can be applied in other industrial sectors (glass, textiles, mining, etc.) that generate other types of waste (liquid effluents, wastewater and gaseous emissions) and as a result with different treatments to those described above, allowing to personalize the system of general indicators and develop an alternative selection diagram similar to that exposed.

In the same way, another series of criteria can be incorporated into the study, either parameters related to the social or economic conditions of the environment, or other factors that could have a critical role in the security of the waste storage and other outputs, using the extensive system of indicators that includes the methodology or incorporating new indicators if necessary.

Finally, a software could be developed to support this methodology, allowing for each of the treatment alternatives, the quantitative determination of effluent outputs, energy consumption, chemical agents, etc.

Acknowledgements. This work has been subsidized through the Plan of Science, Technology and Innovation of the Principality of Asturias (Ref: FC-GRUPIN-IDI/2018/000225). We would also like to thank to Miss Marina Diaz Piloñeta for her accurate critical evaluations and contribution with their ideas to the present research.

\section{REFERENCES}

[1] Abdulhasan, M. J., Anafiah, M. M., Satchet, M. S., Abdulaali, H. S., Toriman, M. E., AlRaad, A. A. (2019): Combining Gis, fuzzy logic, and AHP models for solid waste disposal site selection in Nasiriyah, Iraq. - Applied Ecology and Environmental Research 13(3): 6701-6722.

[2] Achillas, C., Vlachokostas, C., Moussiopoulos, N., Banias, G. (2010): Decision support system for the optimal location of electrical and electronic waste treatment plants: a case study in Greece. - Waste Management 30(5): 870-879.

[3] AEMET (2017): Valores climatológicos normales: Asturias Aeropuerto - Agencia Estatal de Meteorología - AEMET. Gobierno de España. http://www.aemet.es/es/serviciosclimaticos/datosclimatologicos/valoresclimatologicos (accessed: March 17, 2017).

[4] Akınc1, H., Özalp, A. Y., Turgut, B. (2013): Agricultural land use suitability analysis using GIS and AHP technique. - Computers and Electronics in Agriculture 97: 71-82.

[5] Almorox, J., Quej, V. H. (2015): Global performance ranking of temperature-based approaches for evapotranspiration estimation considering Köppen climate classes. Journal of Hydrology 528: 514-522.

[6] Arán, J., Espín, A., Aznar, F., Zamorano, M., Rodríguez, M., Ramos, A. (2008): Environmental decision-support systems for evaluating the carrying capacity of land areas: optimal site selection for grid-connected photovoltaic power plants. - Renewable and Sustainable Energy Reviews 12(9): 2358-2380.

[7] Carniel, A. C., Schneider, M. (2017): Fuzzy inference on fuzzy spatial objects (FIFUS) for spatial decision support systems. - 2017 IEEE International Conference on Fuzzy Systems (FUZZ-IEEE), pp. 1-6. 
[8] Çebi, F., Otay, İ. (2015): Multi-criteria and multi-stage facility location selection under interval type-2 fuzzy environment: a case study for a cement factory. - International Journal of Computational Intelligence Systems 8(2): 330-344.

[9] Chen, D., Chen, H. W. (2013): Using the Köppen classification to quantify climate variation and change: an example for 1901-2010. - Environmental Development 6: 6979.

[10] Chen, L., Olhager, J., Tang, O. (2014): Manufacturing facility location and sustainability: a literature review and research agenda. - International Journal of Production Economics 149: 154-163.

[11] Comision Europea (2003): CELEX1, Recomendación de la Comisión sobre las orientaciones para la aplicación del Reglamento (CE) n $n^{\circ} 761 / 2001$ del Parlamento Europeo y del Consejo. - Comision Europea, Brussels.

[12] Dey, P. K., Ramcharan, E. K. (2008): Analytic hierarchy process helps select site for limestone quarry expansion in Barbados. - Journal of Environmental Management 88(4): 1384-1395.

[13] DOUE (2009): RE (CE) No 1221/2009. REGLAMENTO (CE) $\mathrm{N}^{\circ} 1221 / 2009$ del Parlamento Europeo y del Consejo de 25 de noviembre de 2009 relativo a la participación voluntaria de organizaciones en un sistema comunitario de gestión y auditoría medioambientales (EMAS), y por el que se derogan el Reglamento (CE) $\mathrm{n}^{\circ}$ 761/2001 y las Decisiones 2001/681/CE y 2006/193/CE de la Comisión. - Diario Oficial de la Unión Europea.

[14] Feng, S., Hu, Q., Huang, W., Ho, C.-H., Li, R., Tang, Z. (2014): Projected climate regime shift under future global warming from multi-model, multi-scenario CMIP5 simulations. - Global and Planetary Change 112: 41-52.

[15] Fernández, M., Palacios, H. M., Cabal, J. V. A., Huerta, G. M. M. (2014): Methodology for industrial solid waste management: implementation to sludge management in Asturias (Spain). - Waste Management \& Research: The Journal of the International Solid Wastes and Public Cleansing Association, ISWA 32(11): 1103-1112.

[16] Glatte, T. (2015): Location strategies: methods and their methodological limitations. Journal for Engineering, Design and Technology 13(3): 435-46.

[17] GRI (2005): Suplemento GRI del sector Minería y Metales. - Global Reporting Initiative, Amsterdam.

[18] Haastrup, P., Maniezzo, V., Mattarelli, M., Mazzeo Rinaldi, F., Mendes, I., Paruccini, M. (1998): A decision support system for urban waste management. - European Journal of Operational Research 109(2): 330-341.

[19] Hejazi, R. F., Husain, T., Khan, F. I. (2003): Landfarming operation of oily sludge in arid region - human health risk assessment. - Journal of Hazardous Materials 99(3): 287-302.

[20] IHOBE (1999): Guía de Indicadores Medioambientales para la Empresa. - IHOBE, Sociedad Pública Gestión Ambiental; Ministerio Federal de Medio Ambiente, Bonn; Agencia Federal Medioambiental, Berlin.

[21] Inglezakis, V. J., Moustakas, K., Khamitova, G., Tokmurzin, D., Sarbassov, Y., Rakhmatulina, R., Serik, B., Abikak, Y., Poulopoulos, S. G. (2018): Current municipal solid waste management in the cities of Astana and Almaty of Kazakhstan and evaluation of alternative management scenarios. - Clean Technologies and Environmental Policy 20(3): 503-516.

[22] Kauko, T. (2006): What makes a location attractive for the housing consumer? Preliminary findings from metropolitan Helsinki and Randstad Holland using the analytical hierarchy process. - Journal of Housing and the Built Environment 21(2): 159176.

[23] Köppen, W. (1900): Versuch einer Klassifikation der Klimate, vorzugsweise nach ihren Beziehungen zur Pflanzenwelt. - Geographische Zeitschrift 6: 657-679.

[24] Köppen, W., Geiger, R. (1930): Handbuch der Klimatologie. - Gebrueder Borntraeger, Berlin. 
[25] Kyriakis, E., Psomopoulos, C., Kokkotis, P., Bourtsalas, A., Themelis, N. (2017): A step by step selection method for the location and the size of a waste-to-energy facility targeting the maximum output energy and minimization of gate fee. - Environmental Science and Pollution Research International 25(27): 26715-26724.

[26] Liphadzi, M. S., Kirkham, M. B., Musil, C. F. (2005): Phytoremediation of soil contaminated with heavy metals: a technology for rehabilitation of the environment. South African Journal of Botany 71(1): 24-37.

[27] Milutinović, B., Stefanović, G., Dassisti, M., Marković, D., Vučković, G. (2014): Multicriteria analysis as a tool for sustainability assessment of a waste management model. Energy 74: 190-201.

[28] Milutinović, B., Stefanović, G., Kyoseva, V., Yordanova, D., Dombalov, I. (2016): Sustainability assessment and comparison of waste management systems: the cities of Sofia and Niš case studies. - Waste Management \& Research: The Journal of the International Solid Wastes and Public Cleansing Association, ISWA 34(9): 896-904.

[29] Nouri, D., Sabour, M. R., GhanbarzadehLak, M. (2018): Industrial solid waste management through the application of multi-criteria decision-making analysis: a case study of Shamsabad industrial complexes. - Journal of Material Cycles and Waste Management 20(1): 43-58.

[30] Önüt, S., Soner, S. (2008): Transshipment site selection using the AHP and TOPSIS approaches under fuzzy environment. - Waste Management 28(9): 1552-1559.

[31] Paul, K., Chattopadhyay, S., Dutta, A., Krishna, A. P., Ray, S. (2018): A comprehensive optimization model for integrated solid waste management system: a case study. Environmental Engineering Research 24(2): 220-237.

[32] Peel, M. C., Finlayson, B. L., McMahon, T. A. (2007): Updated world map of the Köppen-Geiger climate classification. - Hydrol. Earth Syst. Sci 11(5): 1633-1644.

[33] Pražnikar, J. (2017): Particulate matter time-series and Köppen-Geiger climate classes in North America and Europe. - Atmospheric Environment 150: 136-145.

[34] Saaty, T. L. (1980): The Analytic Hierarchy Process. - McGraw-Hill, New York.

[35] Samah, M. A. A., Manaf, L. A., Aris, A. Z., Nor, W. (2017): Solid waste management: analytical hierarchy process (AHP): application of selecting treatment technology in Sepang Municipal Council, Malaysia. - Current World Environment 6(1).

[36] Sharma, P., Pandey, S. (2014): Status of phytoremediation in world scenario. International Journal of Environmental Bioremediation \& Biodegradation 2(4): 178-191.

[37] Srdjevic, Z., Kolarov, V., Srdjevic, B. (2007): Finding the best location for pumping stations in the Galovica drainage area of Serbia: the AHP approach for sustainable development. - Business Strategy and the Environment 16(7): 502-511.

[38] Stern, H., de Hoedt, G., Ernst, J. (2000): Objective classification of Australian climates. Australian Meteorological Magazine 49: 87-96.

[39] Ulubeyli, S., Kazaz, A., Arslan, V. (2017): Construction and demolition waste recycling plants revisited: management issues. - Procedia Engineering 172: 1190-1197.

[40] Vaillancourt, K., Waaub, J.-P. (2002): Environmental site evaluation of waste management facilities embedded into EUGÈNE model: a multicriteria approach. European Journal of Operational Research 139(2): 436-448.

[41] Köppen, W., Geiger, R. (1936): Das geographische System der Klimate. - Gebrüder Bornträger, Berlin.

[42] Wibowo, S., Grandhi, S. (2017): A Multicriteria Approach for Selecting the Optimal Location of Waste Electrical and Electronic Treatment Plants. - In: Computer and Information Science. Studies in Computational Intelligence. International Conference on Computer and Information Science. Springer, Cham, pp. 139-147.

[43] WMO (2017): Global Climate Normals (1961-1990). National Centers for Environmental Information (NCEI). - https://www.ncdc.noaa.gov/wdcmet/data-access-search-viewertools/global-climate-normals-1961-1990 (accessed: March 17, 2017). 
[44] Wójcik, G., Jacyno, M., Korkosz-Gebska, J., Krasuska, E., Oniszk-Popławska, A., Trebaczf, D. (2014): Location selection analysis for biological treatment plants for municipal waste. - Journal of Power Technologies 94 (1): 1-19.

[45] Wu, S., Yang, Z. (2018): Optimizing location of manufacturing industries in the context of economic globalization: a bi-level model based approach. - Physica A: Statistical Mechanics and Its Applications 501: 327-337.

[46] Xu, Y., Wu, S., Zang, H., Hou, G. (2014): An interval joint-probabilistic programming method for solid waste management: a case study for the city of Tianjin, China. Frontiers of Environmental Science \& Engineering 8(2): 239-255.

[47] Yadav, B. K., Hassanizadeh, S. M. (2011): An overview of biodegradation of LNAPLs in coastal (semi)-arid environment. - Water, Air, and Soil Pollution 220(1-4): 225-239.

[48] Yoo, J., Rohli, R. V. (2016): Global distribution of Köppen-Geiger climate types during the Last Glacial Maximum, Mid-Holocene, and present. - Palaeogeography, Palaeoclimatology, Palaeoecology 446: 326-337. 